\title{
Modification of wise pattern based design with free nipple areolar complex graft in a case of juvenile hypertrophy of the breasts
}

\author{
Theddeus OH Prasetyono, Vivi V Guizot
}

\begin{abstract}
Abstrak
Juvenile hypertrophy of the breast (JHB) merupakan gigantomastia unilateral atau bilateral pada wanita peripubertal dan merupakan kasus jarang. Kelainan ini terbatas pada payudara berupa pertumbuhan dan perkembangan yang tidak normal. Pembesaran payudara bilateral atau unilateral tidak hanya mengakibatkan gangguan fisik tetapi juga psikis. Etiologinya sulit ditentukan, tetapi kelainan ini menggambarkan adanya hipersensitifitas organ akibat gangguan regulasi endokrin. Terapi terbaik berupa pembedahan yaitu mastektomi atau mammaplasti reduksi. Laporan ini menyajikan kasus seorang wanita berusia 30 tahun dengan JHB. Pertumbuhan payudara kirinya dimulai saat pubertas dan terus membesar selama setahun. Operasi dilaksanakan berupa reduksi mammaplasti dengan wise pattern based design. Setelah dua tahun pasien tidak memiliki tanda-tanda rekurensi dan kedua payudaranya tampak simetris dengan parut yang memuaskan. (Med J Indones 2008; 17: 13-9)
\end{abstract}

\begin{abstract}
Juvenile hypertrophy of the breast $(\mathrm{JHB})$ is a rare condition leading to gigantomastia unilaterally or bilaterally in peripubertal females. The pathology is limited usually to the breast, with otherwise normal growth and development and without any other deformities. The rapid bilateral or unilateral growth of the breast in adolescent girls leads to severe physical and psychological problems. The etiology remains elusive, but it is believed to represent an end-organ hypersensitivity during a period of intense endocrine regulatory stress. The best treatment is surgical whereas the younger patients better treated with mastectomy to anticipate the high recurrency rate, while older women is best treated with reduction mammaplasty. We report one case of a woman who had a unilateral JHB. The growth of the left breast started in her pubertal age and kept growing for one year. She was treated surgically with Wise pattern based design. After two years, she had no recurrent enlargement and aesthetically, the symmetry of both breasts is achieved with a satisfying scar. (Med J Indones 2008; 17: 13-9)
\end{abstract}

Keywords: juvenile hypertrophy of the breast, reduction mammaplasty, wise pattern based design

Macromastia (gigantomastia/hypertrophy of the breasts) which is an uncommon clinical entity, ${ }^{1}$ has been referred to as a massive enlargement of the breasts, unilateral or bilateral, in non-obese women that leads to disproportional to growth of the remainder of the body. ${ }^{1,2}$ Various criteria have been identified to differentiate macromastia from simple breast enlargement, namely breast weight exceeding 600 grams and causing discomfort and stretching of the overlying skin causing ulceration. ${ }^{1,3}$ This disorder is most commonly classified into three types: pubertal/ virginal macromastia/juvenile hypertrophy of the breast (JHB), macromastia during pregnancy (gestational macromastia), and macromastia in adult

Division of Plastic Surgery, Department of Surgery, Faculty of Medicine, University of Indonesia/Dr. Cipto Mangunkusumo Hospital, Jakarta, Indonesia women in whom no initiating cause is identified. ${ }^{1}$ In addition, this disorder may be associated with penicillamine therapy. ${ }^{1,4}$

In this paper we will discuss the first type of macromastia regarding the case report.

JHB is a rare condition leading to gigantomastia unilateral or bilaterally in peripubertal females. ${ }^{2,6-8}$ The first case of JHB was reported by Durston in 1669. ${ }^{3,6,9}$ and only 75 cases reported ever since. ${ }^{2,7,8}$ The pathology is limited usually to the breast, with otherwise normal growth and development and without any other deformities. ${ }^{3}$ The rapid bilateral or unilateral growth of the breast in adolescent girls leads to severe physical and psychological problems. ${ }^{2,6,7}$ The etiology remains elusive, but it is believed to represent an end-organ hypersensitivity during a period of intense endocrine regulatory stress. ${ }^{2,8}$ 
In this case we will report one case of a woman who had a unilateral JHB who never received any hormonal medication and where the affected breast has stopped growing. She was treated surgically and there was no recurrent hyperplasia after two years of follow up.

\section{CASE REPORT}

A thirty year-old woman weighting $45 \mathrm{~kg}$ and $154 \mathrm{~cm}$ in height, came with a chief complaint of having a severe breast asymmetry. The enlargement of the left breast started 15 years ago during her prepubertal age. Despite of having enlargement of both breasts, her left breast enlarged more rapidly and progressively. After 3 years the growth of the left breast gradually ceased. She had one child and there was no rapid enlargement on the affected breast during pregnancy. Her left breast did not produce milk after parturition. There was no history of taking any hormonal medications nor prolonged NSAID consumption. Her past medical and family history was unremarkable. Examination revealed a woman with an ideal body shape with huge and pendulous left breast that almost reached the pubis in standing position. The skin of the affected breast was thin with prominent superficial veins and dilated nipple. There was no discreted mass felt, no nipple discharge, and no lymphnodes enlargement. There were no abnormalities on her blood test. In April 2004, she underwent a reduction mammaplasty with a free nipple graft. The result is very satisfying. Both breasts are symmetrical with a minimum scar.

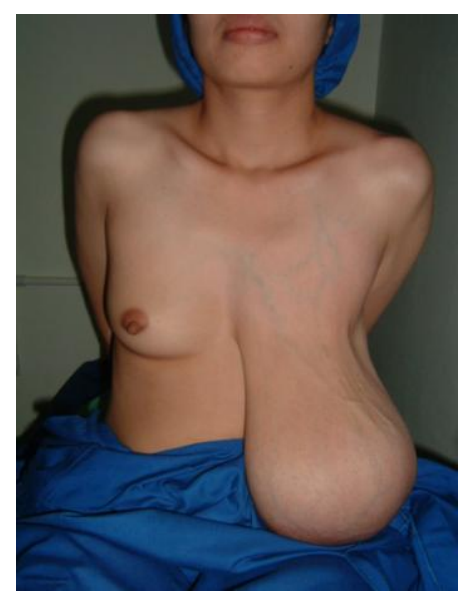

Figure 1. Pre operative condition of the patient (With permission from the patient).

\section{Surgical technique of the modification of Wise pattern based design $(T \text { inverted })^{10}$}

With the patient erect, the breast meridian is established by dropping a line from the midclavicle through the nipple and continuing inferiorly across the inframammary line The level of the inframammary fold is transposed to the anterior breast and marked on the breast meridian. It was also confirmed to be $19,5 \mathrm{~cm}$ as per normal contralateral breast from midclavicular or sternal notch point. Diverging lines as the limbs of the pattern are drawn from this key point and pass as, if they are lengthened, tangents to either side of the dilated areola. Both lines is measured $5 \mathrm{~cm}$ as it follows the meridian line of the normal contralateral breast from nipple to inframammary line. Instead of making a wire keyhole pattern, a circular design of 35 $\mathrm{mm}$ diameter encircling the future nipple position is drawn to be deepithelialized later. From the limbs of the pattern, lazy $\mathrm{S}$ based lines are directed medially and laterally to intersect the inframammary fold, which has also been indicated.

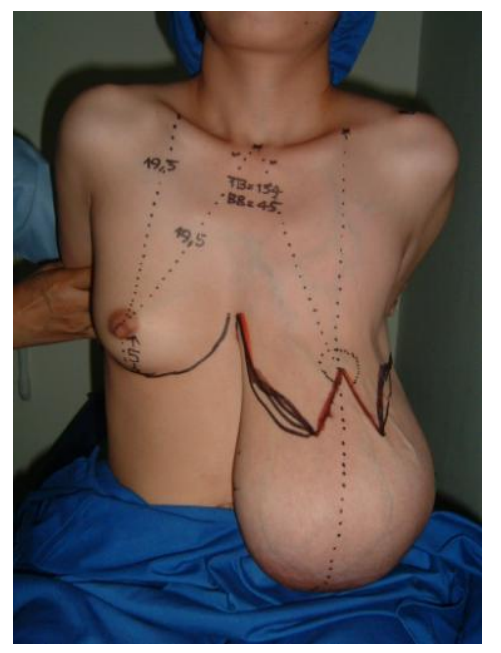

Figure 2. The design of the surgery to reduce the hypertrophic breast using a modification of the Wise pattern technique (With the permission from the patient)

The procedure is begun by removing the nipple-areola complex rapidly with the diameter of $35 \mathrm{~mm}$. It is then set aside in a moist saline gauze. 

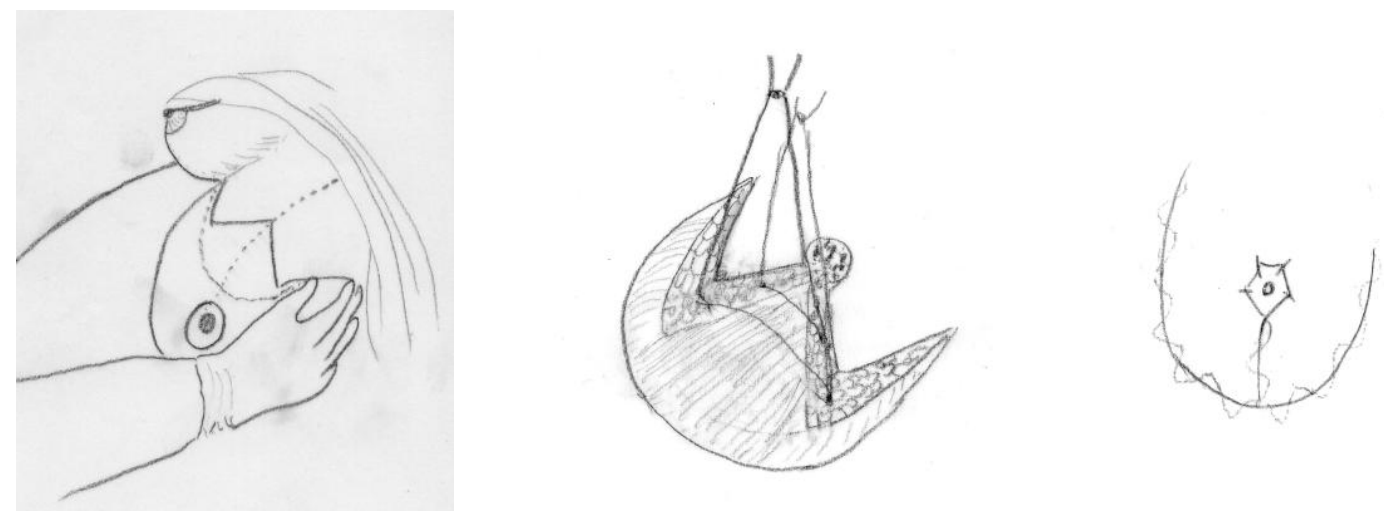

Figure 3. The sequences of the surgery. a) Rechecking the amount of the breast tissue to be resected Never excise too much. $b$ ) The limbs are gathered with absorbable sutures. Dotted area is to be de-epithelialized as the future nipple site. c) Final result with NAC graft on its position

We prefer, however, to retain superiorly based parenchyma which follows the diverging limbs of the pattern. This retained tissue is designated with a prediction of the mass volume comparable to the normal contralateral breast.

Clearly the greatest pitfall in this otherwise straightforward procedure is the amputation of the excessive breast tissue, leaving only superior flaps with subcutaneous tissue and little breast tissue as mentioned by Spear and Little. ${ }^{10}$ If the breast is allowed to hang pendulously, gravity plus virtually the entire gland below the level of the amputating blade, presenting us with a regrettable surprise when refashioning an inadequate breast from the remaining superior flaps. Thus, on the other hand, the gland is gathered and presented in a spherical fashion by an assistant, the amputating blade leaves a significant amount of parenchyma superiorly. The dictum that more can always be later prevails here.

The amputating incision is carried perpendicularly down to the chest wall musculature. The inframammary incision is similarly carried perpendicularly to the musculature. The large intervening wedge of gland is then dissected progressively from medial to lateral away from the muscle fascia, maintaining exact hemostasis as the resection progresses. The central portion of the remaining superior gland, including the deskinned portion is then dissected from the underlying muscle fascia superiorly creating a narrow subglandular pocket. Some absorbable sutures are used to gather the pillars of limbs parenchyma.

This tissue then fulfils the subglandular pocket and fixed to the pectoralis fascia with an additional suture. With closure of the remaining skin margins, a pleasing conical shape is created, with the infolded central breast tissue forcing an impressive projection. Closure is completed in the standard fashion working from the extremities centrally.

The defatted nipple-areola complex is sutured in place and secured with a tie-over dressing. It is important not to thin the areolar portion of the graft excessively during the defatting process, so that the resulting areolar graft has a more natural appearance.

Similarly, ductal tissue is left within the papilla, to favor nipple projection. A greasy dressing with wet gauze made bolus is then tied in place over the complex and is removed at day 6 . The mass resected was 1100 grams. 


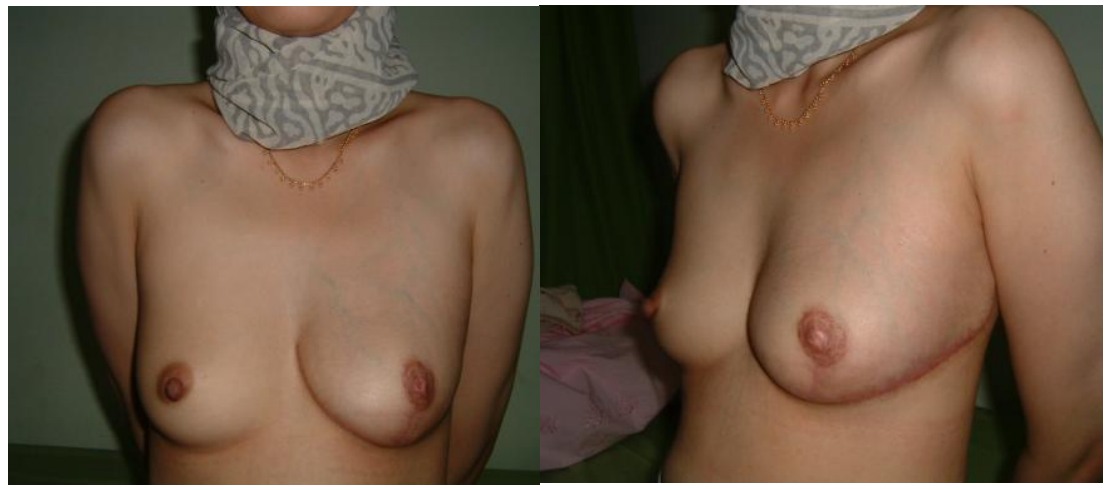

Figure 4.Two months post operative view. Symmetrical breasts with satisfying scar. (With permission from the patient)

\section{DISCUSSION}

JHB is a rare and unusual condition of unknown origin. ${ }^{2,6,7}$ In almost all cases, it develops sporadically ${ }^{6}$ and only two cases of familial nature were ever described $^{6,8}$ which one case of familial JHB is accompanied by congenital anonychia reported by Yehudain et al for the first time. ${ }^{6,7}$ These two conditions might be genetically inherited as separate traits in the same extended family or as a combined phenotype of a single gene disorder. ${ }^{6}$ This family presents a unique opportunity to investigate the etiology of these rare conditions.

True JHB is characterized by rapid growth of the breasts, unilateral or bilateral, disproportionately to the remainder of the body. ${ }^{2,6,7}$ Normally, the growth of the glands begins just prior to or shortly following menarche, with an age range of 8 to 16 years ${ }^{7}$ whereas the development and physical enlargement of the female breast usually occurs gradually over a period of 3-5 years, during which there is proliferation of the stromal and ductal components. ${ }^{2}$ In contrast to the normal pattern of slow and progressive enlargement, JHB is a rapid and massive enlargement of one or both breasts. ${ }^{2,7,8}$ Patients usually experience an initial period of especially brisk growth lasting to 3-6 months, followed by a longer period of slower but continued growth that, if untreated may last well into the child bearing years. ${ }^{8}$ Morimoto et al as cited by Yehudain $^{6}$ suggested that the etiology of JHB is related to local hypersensitivity of estrogen receptors for estrogen. ${ }^{6}$ In a study by Jabs et al analyzing estrogen receptors in 25 reduction mammaplasties due to breast hypertrophy revealed that all speciments are negative estrogen receptors count. ${ }^{12}$
This patient is also experienced rapid growth of her left breast when she was 15 years old. As far as she can remember the growth lasted for 1 year, and then the growth gradually ceased.

Patients will report symptoms of macromastia that are similar to those in patients with macromastia in any etiology: breast pain, back and neck pain, slouching postures, shoulder grooving from brasserie straps, hygienic difficulties, intertriginous lesions at the inframammary folds. ${ }^{6,7}$ Patients with JHB often are more concerned with the psychological and social sequelae of the disorder. ${ }^{6-8}$ They have great difficulty finding properly fitting clothes and are unable to participate in sport activities. Many patients refuse to attend social events and become virtually homebound. ${ }^{8}$ This patient works as a teacher, she is an accepting person as most Javanese people. She did not go out often, she also did not attend social gathering from the same professions.

The physical examination of JHB will reveal an otherwise healthy, normally developed girl with strikingly disproportionate enlargement of one or both breasts. ${ }^{3,6-8}$ The affected breasts are pendulous in appearance, with dilated nipples and areola. The superficial veins are prominently dilated. Skin changes range from thinning to ulceration and necrosis secondary to compromised blood supply from excessive tension on the skin. ${ }^{3,8,11}$ Overall, the breasts are diffusely firm and sometimes tender to palpation. ${ }^{6,8}$ JHB is not associated with axillary lymphadenopathy or galactorrhea. ${ }^{6,7,8}$ Spinal deformities secondary to excessive weight may be noted, including kyphosis, compensatory lumbar lordosis and scoliosis in asymmetrical cases. ${ }^{8}$ This patient despite of having 
large, pendulous left breast she has an ideal body shape. The left breast has prominent dilated superficial veins and also dilated nipple and areola. Never had any history of having nipple discharge, and from physical examination we did not find any enlargement of the axillar lymonodes. Also there are no signs of spinal deformity.

Levels of serum estrogens, progesterone, prolactin, and gonadotropins (FSH, LH, cortisol) are within normal limits. The number of estrogen receptors in the breast tissue is not elevated. ${ }^{7-9}$ Netscher reported that in JHB, even of the unilateral type, there is no necessary to perform serum hormonal level assays. ${ }^{9}$ We did not perform any hormonal level assays for the patient.

Imaging studies should be pursued to rule out tumors. ${ }^{8}$ Mammography is notoriously difficult to interpret in young women because of the density of the breast tissue. When a reading of the mammogram is possible, benign findings are the rule, ranging from homogenous density to mastopathy. ${ }^{8}$ Sonographic examination rarely provides useful information and is indicated only if discrete masses are present. Magnetic resonance imaging may be of more use in defining the breast architecture and occult pathology. ${ }^{8}$ For this patient we also did not perform any imaging examination due to her density of the breast and no discrete mass was palpated.

Microscopically, breast tissue in JHB presents with no tumor capsule, the stroma is less organized, and ductal component is more prominent. ${ }^{8}$

Differential diagnosis of unilateral enlargement of the breast in adolescence includes, in decreasing order of frequency : giant fibroadenoma, phyllodes tumor (cystosarcoma phyllodes), JHB and gestational gigantomastia. ${ }^{9}$ The giant forms of fibroadenomas are the most likely to mimic JHB, because they can grow very rapidly to a large size with associated warmth, dilated veins, and skin thinning in the region of the tumor. Their consistency may be similar to the relatively normal breast texture of JHB ${ }^{8}$ The majority of fibroadenomas are discrete nodules that can easily be shelled out surgically and look grossly different from surrounding mammary tissue. ${ }^{9}$

Phyllodes tumors may grow quickly to a massive size with associated skin changes as well as JHB. This picture is reminiscent of unilateral JHB, although phyllodes tumors usually present as a heterogenous consistency, well circumscribed mass rather than the diffuse and moderately firm enlargement seen in $\mathrm{JHB}^{8}{ }^{8}$ It is generally believed that these three lesions (fibroadenoma, JHB and phyllodes tumor) share a common etiology, namely an exaggerated response to normal stimulus. Thus a generalized response would produce virginal hypertrophy, and a localized response would produce fibroadenoma and even phyllodes tumor. $^{9}$

Gestational gigantomastia is a rare disorder with disproportionate massive enlargement of one or both breasts that may or may not undergo spontaneous regression after parturition. ${ }^{3}$ Its incidence is 1:100000 pregnant women. ${ }^{3}$ The clinical picture of rapid and massive enlargement of the breasts closely resembles JHB. The similarity of these two conditions raises the possibility that recurrent pathologic breast enlargement may occur during future pregnancies in the group of juvenile hypertrophy. ${ }^{6}$

The approach of the treatment for JHB remains controversial. It includes psychological, pharmacological, and surgical aspects. ${ }^{5}$

It has been well documented that any surgical treatment shy of total ablation of all breast tissue will result in recurrent hypertrophy during the period of end-organ hypersensitivity. ${ }^{7-9}$ Kupfer et al reported retrospectively from $15 \mathrm{JHB}$ cases treated with total mastectomy from 1910-1982, two patients required re-resection due to recurrence hypertrophy, one required another three re-excision (at 4,12 and 48 months after first operation). In contrast, 14 JHB cases treated with reduction mammaplasty from 1937 - 1988, only four cases showed no recurrence hypertrophy. The rest (ten cases) required further re-excision between 6 months -4 years postoperatively). ${ }^{7}$ Baker et al reported four cases treated with reduction mammaplasty, all of them need subsequent further reduction due to recurrence hypertrophy whereas one of them recurred due to pregnancy (gestational gigantomastia). ${ }^{8}$ Netscher et al reported one case treated with reduction mammaplasty and one year after the first operation, the contralateral breast became enlarged rapidly, prompting surgical reduction on that side. ${ }^{9}$ If incomplete removal of mammary tissue has occurred, the patient is at risk for these residual elements of breast tissue to enlarge, either progressively or in response to a hormonal stimulus such as pregnancy. ${ }^{8}$ The hypertrophy of the incompletely resected breast tissue to enlarge to the point that it requires surgical removal. ${ }^{8}$ Baker et al suggested that older patient may be treated definitely 
with reduction surgery alone and young patients should be treated by subcutaneous mastectomy because of high rate of recurrence. ${ }^{8}$ For a young age patient who agrees to subcutaneous mastectomy as a first and hopefully a definitive operation, the reconstruction with implants should be delayed for a few years for follow up of possible recurrence and need for repair. ${ }^{8}$ The definitive breast enlargement with implants should be performed at the age individually appropriate for each patient. ${ }^{5}$ Although mastectomy with implant reconstruction offers definitive treatment, the patient is susceptible to complications associated with prosthetic breast implants. $^{8}$

Supplemental hormone therapy has been demonstrated to help reduce the risk of recurrence after reduction surgery and to avoid the need for complete mastectomy. ${ }^{2,7,8}$ It has been used either alone or as an adjunct to breast reduction. ${ }^{8}$ Several antiestrogen drugs such as medroxyprogesterone (depo-provera), dydrogesterone (gynorest), and tamoxifen citrate (novaldex) have proved useful in arresting breast development. ${ }^{2,6}$ Tamoxifen was found to be the most effective remedy in arresting recurrent breast enlargement after breast reduction surgery. ${ }^{5,8}$ A few authors recommended hormonal therapy for at least six months. In patients who fail to respond to an adequate trial of an antiestrogen, surgical therapy should be considered - either a reductive mammaplasty or a subcutaneous mastectomy with immediate or subsequent surgical implants. ${ }^{2}$ Other authors suggested that young age patients should be taken into considerations before prescribing hormonal treatment due to its potential risks and disadvantages in using these drugs. 7,9

Surgical strategies in treatment of JHB are very complicated as well. Breast reduction is the accepted strategy for treatment of JHB. This procedure should focus on the way of areola-nipple handling. Huge size of breast usually requires free areola-nipple graft technique. Yehudain et al use McKissock technique in three out of four patients he reported with all of them were performed a free areola-nipple graft. ${ }^{5}$ Yehudain et al also reported that they performed one McKissock procedure surgery without free nipple graft despite the pedicle length reach $50 \mathrm{~cm}^{5}$ All the areola-nipple complex survived.

The choice of the surgical technique for the patient is a $\mathrm{T}$ inverted (Wise pattern based) design due to if we use a true bipedicle or superiorly based pedicle flap procedure, the pedicle would be too long so that the whole pedicle including NAC might become necrotic. The ideal comparative of width and length of pedicle is maximally 1:5. Although Yehudain et al reported one successful case that's done with pedicle length of $50 \mathrm{~cm}$, there is no evidence of intra and post operative picture.

This patient's clinical condition is similar to JHB though the affected breast is already stopped growing or the growth itself has become so slow that the patient herself did not even notice. She is an accepting person like most of Javanese people and never have thought of undergoing a surgery before. She decided to undergo surgery due to her mother in law commented about her body shape.

The patient did not undergo mammography or ultra sound examination due to the density of the breast tissue will not represent the exact pathologic condition and ultrasound imaging rarely provides useful information, and only indicated if discrete nodules were palpated.

This patient is best treated surgically with reduction mammaplasty based on evidence that older woman is unlikely to have recurrent enlargement after surgery due to the hormonal regulation stress period had passed.

The result of the surgery is divided into aesthetically and functional. Aesthetically, the symmetry of both breasts is achieved. Two months post operatively, the scar is already satisfying for the patient and both breast looked symmetrical.

After two years, the scar is hardly seen, the color is similar with the surrounding skin, feels soft and not itching.

Functionally, we divided into:

1. Sensibility : two weeks post operatively the sensibility of the affected breast was less than the contralateral side. The nipple felt numb. After two years the sensibility of the breast is similar to the normal side but the nipple-areolar sensibility still feels numb.

2. The softness of the breast is also felt symmetric both sides. Subjectively the patient feels satisfied about the affected breast.

3. Sexual activity of the patient is increased both quality and quantity. It is due to her being more confident about her body image.

4. In regard of social relationship. She is withdrawn before surgery. Avoiding social gathering even with her friends in the same professions society 
(teachers). After operation she gradually opened herself to attend those kinds of gatherings.

After two years, there is no recurrent enlargement and aesthetically still satisfying. Therefore, although the patient did not undergo histopathologic examination, clinically it is similar with JHB.

\section{SUMMARY}

Juvenile hypertrophy of the breast is a rare case that is characterized with rapid enlargement of the breast in peripubertal women. It is best treated with surgical approach. Due to high recurrence rate the patient should be faced with some options: Reduction mammaplasty with or without hormonal treatment or subcutaneous mastectomy with NAC preservation and subsequent reconstruction.

The patient reported here is a clinical JHB that has undergone breast reduction operation using $\mathrm{T}$ inverted technique based on modification of Wise pattern design. The result is excellent aesthetically and functionally after two year of follow up. Clinically there is no recurrent enlargement.

\section{REFERENCES}

1. Zargar AH, Laway BA, Masoodi SR, Chowdri NA, Bashir MI, Wani AI. Unilateral gestational macromastia - an unusual presentation of a rare disorder. Postgrad Med J 1999; 75: 101-5.

2. O'Hare PM, Frieden IJ. Virginal breast hypertrophy. Ped Dermatol 2000; 17: 277-81.

3. Yehudain JG, Kogan L, Cohen HI, Falik-Zaccaib TC. Familial juvenile hypertrophy of the breast. J Adolesc Health Care 2004; 35: 151-5.

4. Kupfer D, Dingman D, Broadbent R. Juvenile breast hypertrophy : report of a family pattern and review of the literature. Plast Reconstr Surg 1992; 90: 303-9.

5. Sarda AK, Kulshresta VN, Bhalla SA, Singh L, Chaturvedi UK. Macromastia of pregnancy : a unique presentation of this rare clinicohistopathological entity. Indian J Plast Surg 2004; 37: 74-6.

6. Baker SB, Burkey BA, Thornton P, LaRosa D. Juvenile gigantomastia: presentation of four cases and review of the literature. Ann Plast Surg 2001; 46: 517-26.

7. Netscher DT, Mosharrafa AM, Laucirica R. Massive asymmetric virginal breast hypertrophy. Southern Med J 1994; 89: 434-7.

8. Jabs AD, Frantz AG, Smith-Vaniz A, Hugo NE. Mammary hypertrophy is not associated with increased estrogen receptors. Plast Reconstr Surg 1990; 86: 64-6.

9. Mayl N, Vascomez LO, Jurkiewicz MJ. Treatment of macromastia in the actively enlarging breast. Plast Reconstr Surg 1974; 54: 6-12.

10. Desat SN. Sudden gigantism of the breasts: drug induced? British J Plast Surg 1973; 26: 371-2.

11. Finer N, Emery P, Hicks B. Mammary gigantism and dpenicillamine. Clin Endocrinol 1984; 21: 219-22.

12. Spear SL, Little JW. Reduction mammaplasty and mastopexy. In : Aston SJ, Beasley RW, Thorne CHM, editors. Grabb and Smith Plastic Surgery. $5^{\text {th }}$ ed. New York : Lippincot-Raven Publisher; 1997. p. 739-41. 